画像処理-1

座長 堤 直葉（越谷打立病院）

96. エネルギーサブトラクションフィルム法による 被 写体の質的検討

国立循環器病センタ一放射線䛦潦部 ○田中 勲・若松孝司

Energy Subtraction 法は，2 種の異なるエネルギーの X線を用いて，同一被写体を測定し，その2 種の画像閧 の沙算を行なって目的とする対象をコントラストよく表 わそうとするすので，フィルムによるEnergy Subtractionにより， Iodine を写真上に強調し表現するととが できたまた，DupおよびSubtractionを行なう場合， フィルムを使用するため, 濃度域の限界があった。

今後, 撮影パルスごとに，X線エネルギーを高速で切 り換えることが可能となれば，身体の動きに対しても対 応できるむのとなろう。

\section{CT 画像表示装置によるX線フィルム像の観察}

福島県立医科大学放射線科

○片會俊彦・鉿木憲二・伊藤陸郎 份藤孝則・上曰 稔

[目的]X線字真フィルム濃度をドラムスキャンデン シトメータによりディジタル化し，コントラスト処理等 を加えることによって，X線フィルムの持つ濃度分解能 の限界付近の表示を試みた。

〔結果】 (1) 水のうファントムによる奏験で, EMI值 10程度は分解四能であった。また，X線写真のみかけ上 の濃度分解能向上に断層写真が有効であった. (2) 鶏卵 の断層写真において，X線の被写体 Pass 補正のための ボーラスが濃度分解能の问上に有用であった。 (3) 造影 剤静注後の頭部断層写真より，血管腫が描出された．以 上が結果であるが，フィルムの処理時に生ずる濃度のム ラやキズ等による影響も大きいととがわかった。

98. Computed Radiagraphy 画像イメージング方法の 検討

名古屋保健衛生大学病院

○根原孝彦・立木秀一・沢田武司 小西六写真工業株式会社

黑国祐次・川栄健次

今回，われわれは CR 画像における記録系の改良に着 目し，CRT のディスプレイ機構の高精度化及び CR 用 フィルムの検討を行った，その絬果，起查線数 $\mathrm{i}, 050$ 本 のディスプレイでは 525 本に比べ，过縁部の山山が少く 滑らかな画像が得られ走查線が目立たなかった。臨㦿例。
でも脚野や血管などの微細部の現出が良好であった。 $\mathrm{CR}$ 用フィルムとして，サクラタイプC及びタィプUの 両者共, 写真濃度一CR 值曲線の面線性は良好であった が，特にタイプUは低濃度部の直線性が優れていた。 ま た，タイプUはタイプCに比べ特性曲線がローガンマの ため撮影条件のラチュードが広く，カメラモニタの調整 が容易で使い易加った。

\section{9. 大腸ポリープに対する False Positiveの検討} 兵厙医科大学病院中央放射線部

○森下幸一・仲座良造・双江保夫 荘園信一郎・堀 真規・佐々林末広 山田英司

〔目的】大腸二重造影ポリープ像における False Positiveの要园となる気泡除影とポリープ像との判别䜌断 について検討を行なつた。

〔結果〕内視鏡診断との眮では，X線診断の53\%が False Positive であった。

ポリープ像は，接線効果によりリング周囲の濃度の降 下率が大きい，乙れに比べ Air 像ではBa との表面張力 によりりングの濃度降下率が小さく挗の濃度が周辺に 比べ高くなっている.

また視覚的に判定しにくい濃度領域をコントラスト強 調等の函像処理を試みるととにより，雨者の鑑别がより 一層著明となった。

100. Digital Subtraction Image $の$ 基礎的検討

国立循環器病センター放射線彭療部 ○早崎正信・大西義隆 坟下善治・省組一男

〔目的〕DR装置による基本似な拜験を行い，DSAの 臨休例之合わせ，この利点及じ問題点を考察する。

〔結果〕本装置は，墔林上有效な $2 \%$ 濃度(76\%Uro.) で $2 \mathrm{~mm} \phi$ の造影郕識別能在有し, 被瀑線量も従来の血 管造影に比べ少ない. 㸛床では, 各動・静脈, 心臓など 種々の部位で満足できる所見が得られた。 また，手技が 簡便で, 静脈経ゆえ侵襲度も低く, 実時間で正確な subtraction 像が術中表示でき, digital 量なので後処理む加 えられる. 反面, 腸内ガス・体動による障害陰影（腹部 圧迫などで対処）多くの系を通るためにおこる noiseの 影響, 解像力の少化など問題も多い. 今後, 臨床経験に 基づいて性能问上をはかり，様々な可能性を見いだした ᄂ.

\section{座長築約}

96〜100 席の演題は画像処理の演題のう方, 展示発表 の形式のグループである. そのためか, 演題間の共通点 
そ乏しく，一題づつ記すとととした。

[96] X線管電在 $60 \mathrm{kV}$ と $130 \mathrm{kV}$ で撮影した被写体 コントラストの違う 2 枚の写真のサブトラクションによ り，造影された像を見やすくする方法である．演者あ言 っているように装置の開発が実用化につながると思われ る。動きのある被写体にはこの方法は有効である。

[97]CT 画像表示装置で，ディジタル化し，画像処 理したX線写真を見るととを目的としている，今回は， 断層写真のコントラストを高めたり，スムージングをか けて，目で見えなかったものが見えてくるかどうかを試 みている.ディシタル化の処理条件の質問（安政，兵庫 医大）に対し，アパーチャサイズとサンプリングピッチ は共に, $100 \mu \times 100 \mu, 1$ つのマトリクスの大きさは0.1 $\mathrm{mm} \times 0.1 \mathrm{~mm}$ となるが $\mathrm{CT}$ の像再成、トリクス数が, $320 \times 320$ であるから表示する時, 大きい像が必要であれ ば大きな範囲を平均化するという方法を取っていると述 べられた：私としては，見えなかったものが見えるよう になる過程における信号と雑音に対し，不安を感じるが， 断層写真を選んだととが良かったと思われる.

〔98] CT (CR) 画像の改善のため CRT の走查線数 を 525 本から 1,050 本にしたとと, CT 用フィルムの比 較についての 2 本立の発表であった. CT 画像自体の解 像限界が, 示されている写真のテストチャートの一番細 い所 $(0.8 \mathrm{~mm})$ 附近であるとのことから考えて, 走査線 数を倍にしてあ解像力があまり向上しないと思われる. 走査線数を示したときCRT の撮影視野む明記してくれ れば解像力むわかりやすいと思う。また CT の像再成、 トリクス数も. CRT 画像の向上の表現法に工夫がほし かった，一方，フィルムの比較に対しては，ラチュード タイプのフィルムは条件合わせが楽というのむ一寸困る し仕事に役立つととをやっておられるのだから，次回を 期待したい.

〔99〕注晹検査におけるポリープ像と気泡像について， ミクロフォトメータで走査して，読みずき（False Positive）を減らそうという試みである.False Positive と判 定したのは内視鏡の結果との比較であった。ポリープの 型によって出方が違ってくるのではないだろうかという 質問（国立東二，大棒）に対し今回はポリープの分類別 にはやうってないという答えであった，座長として，造影 剤や撮影条件によって変わらないかと質問した．処理前 の写真を何人かで読影し，それを ROC 曲線で表わした りして，走查した結果をあわせてもおもしろいと思われ る.見おとし (False Negative) についても検討してほ しい.
[100]ディジタルサブトラクションアンギオグラフィ のファントム実験と臨床例を示したものである. $2 \%$ の 造影剂濃度で直径 $2 \mathrm{~mm}$ の穴が識別できたと岁る。ガス 像の動きによるアーチファクト等いろいろ問題もあるが 方法として発展が期待される、線量測定等の迫加があっ た。

新しい分野のためか質問が少なかった。展示資料に対 し部屋が大きく，見えない会員が多かった。これならス ライド方式の方が良いのではないか．坐長羊演者皇加 者も展示の前で話し合った雾用気が懐しい.

\section{RI-1 体外測定-1}

座長 谷口金吾 (広島大学)

101. シンチスキャナーおよびピンホールカメラ同時測 定甲状腺像 400 症例の比較

近畿大学医学部附属病院中央放射線部

○坂下太郎・川井弘美・船越 猛

昭和54年11月から57年 1 月間に両法同時施行した 400 例余について比較検討した。 使用装置は 5 付スキャナ Scc-150w とダイナカメラ $3 \mathrm{C}-12$ である. MTF 評価は ピンホールコリメー夕付 3C-12 が一番優れ, 次いで高解 像力コリメータC 付スキャナ, 高感度コリメータ B 付ス キャナの順となった。コりメータB像は腫大ぎみに描出 され，ピンホール像は陕部が拡大してみえるが，コリメ 一タ C 像と相似の像であった. Hot および Cold nodule の描出能はピンホールカメラが優れていたが，ヨード低 摄取例ではスキャナB像が良い. また，ピンホールカメ ラの撮像計数・時間比汃らヨード提取率を回帰直線より 求めるととが可能であった。

102. ピンホールコリメータ装着シンチレーションカメ ラによる胆道末端部運動動態の解析（第 1 報） 基 礎的検討

和歌山県立医科大学放射線科

○鳥住和民・津田佳則・根来良典 国保那賀病院 RI 室 上芝教昭

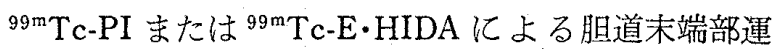
動機能の解析を目的とした, 解像力の良いピンホールコ リメータ使用による検査方法を検討し, 良好な成績を得 た。

【基礎的検討】 (1) 等感度分布曲線, (2) 減弱曲線, (3) 抁大率, (4) ピンホール直径について, など.

〔臨床的検討〕(1)健常例，(2)総胆管結石で乳頭形 成術を施行した症例，(3) 胆石様症状を訴えているが胆 道系に何ら器質的病変のみられない症例など. 